\title{
PLA ANYAGBÓL KÉSZÜLT PRÓBADARAB ANYAGTULAJDONSÁGAINAK KÍSÉRLETI DINAMIKAI VIZSGÁLATA
}

\section{EXPERIMENTAL DYNAMICAL ANALYSIS OF TEST PIECES MATERIAL PROPERTIES MADE BY ADDITIVE PRODUCTION TECHNOLOGIES}

\author{
Kovács Bálint Ádám ${ }^{1}$, Ficzere Péter ${ }^{2}$, Török Ádám² \\ ${ }^{1}$ Budapesti Müszaki és Gazdaságtudományi Egyetem, Közlekedésmérnöki és Jármü- \\ mérnöki Kar, Jármüelemek és Jármü-szerkezetanalízis Tanszék, Cím: 1111 Magya- \\ rország, Budapest, Stoczek utca 2.; Telefon: +36-1-463-1739; Fax: +36-1-463- \\ 111/5857; enzo-b@hotmail.com \\ ${ }^{2}$ Budapesti Müszaki és Gazdaságtudományi Egyetem, Közlekedésmérnöki és Jármü- \\ mérnöki Kar, Jármüelemek és Jármü-szerkezetanalízis Tanszék, Cím: 1111 Magya- \\ rország, Budapest, Stoczek utca 2.; Telefon: +36-1-463-1739; Fax: +36-1-463- \\ 111/5857; ficzere@kge.bme.hu
}

\begin{abstract}
The recent years 3D printing became a hot topic, however it's hard to design parts without a deep understanding of the material properties. The aim of this study is to estimate the modal parameters and the damping properties via experimental dynamic analysis of a part made from $P L A$. We will study the effects of the different directions of printing. With the results we can provide data for the FEM softwares' input.
\end{abstract}

Keywords: experimental modal analysis, additive manufacturing, natural frequency, mode shapes, polymers.

\section{Összefoglalás}

Az utóbbi időben egyre népszerübb téma a 3D nyomtatás, azonban az alkatrészek méretezése az anyagtulajdonságok pontos ismerete nélkül nehézkes. A dolgozat célja, hogy kísérleti dinamikai vizsgálatok során becsüljük egy PLA anyagból készült test modális paramétereit, majd csillapítási tulajdonságait. Megvizsgáljuk a nyomtatás irányának hatásait. Az eredményeket felhasználva a későbbiekben adatokat szolgáltathatunk a végeselemes programok inputjának megadásához.

Kulcsszavak: kísérleti modális elemzés, additív gyártástechnológia, sajátfrekvencia, lengéskép, polimerek.

\section{Bevezetés}

Viszonylag új technológiáról lévén szó, az additív gyártástechnológiák óriási ütemben fejlődnek. Ennek velejárója, hogy a 3D nyomtatóval így készített alkatrészek elöállítási költségei is fokozatosan csökkennek, egyre több felhasználó számára válik elérhetővé a technológia.

Az additív gyártástechnológiák megjelenésével egy időben megnőtt a biológiailag 
lebontható műanyagok jelentősége, különös tekintettel a környezetvédelmi szempontokra [6]. Ilyen anyag a politejsav (PLA), amit az alacsony elóállítási költségének köszönhetöen egyre szélesebb körben alkalmaznak.

A rendkívül rugalmas gyártástechnológia, és a környezetbarát anyag együttese elörevetíti, hogy a jövőben tovább szélesedik az alkalmazási területe a PLA anyagból additív gyártástechnológiával készült alkatrészeknek. A gépészeti alkalmazások tervezéséhez elengedhetetlen az anyagtulajdonságok pontos ismerete. Áttekintettük a vizsgált PLA anyag anyagtulajdonságaival kapcsolatos szakirodalmakat. Azonban a témában kevés olyan publikáció van, ami az anyagtulajdonságok modellezésével is foglalkozik. Ugyanazon anyagjellemző tekintetében az egyes publikációk nagyon szélsőségesen különböző értékeket közölnek [2][3][4][5]. A kutatás célja, hogy jobban megismerjük az így készített alkatrészek csillapítási tulajdonságait, valamint az additív gyártás technológiai paramétereinek az anyagtulajdonságokra gyakorolt hatásait.

\section{Irodalmi áttekintés}

A rendelkezésünkre álló irodalom tanulmányozása során megbizonyosodtunk róla, hogy a test elhelyezése a nyomtatóban jelentős mértékben befolyásolja az anyagjellemzőket: az ,álló” próbatestek szakítószilárdsága jelentősen kisebb, mint a másik két esetben [3][4]. A mértéke az egyes tanulmányokban nem egyforma, köszönhetően a különböző nyomtatási paramétereknek. Az eredményekből megállapítható, hogy álló próbatestnél körülbelül 0,4-0,5szeresére csökken az anyag terhelhetősége [2][3].

A rétegek síkjára merőleges síkokban az anyag hasonlóan viselkedik [3]. Kijelenthetô tehát, hogy az additív gyártástechnológiával gyártott tárgyak ortotróp anyagjellemzőket mutatnak.

\section{Módszer}

A szakirodalom tanulmányozása, a kísérleti, gyártási, alkalmazási tapasztalatok azt mutatják, hogy az additív technológiával gyártott alkatrészek nem mutatnak izotróp anyagtulajdonságokat. $\mathrm{Az}$ anyagtulajdonságok ortotróp jellege a 3D-s nyomtatás irányfüggésével magyarázható [2][3]. Polimer anyagból készült alkatrészek kísérleti vizsgálatai a dinamikai modellezéssel kapcsolatos problémákat is felvetnek.

A cikk egy prizmatikus hasáb kísérleti vizsgálati eredményeit mutatja be. Három darab, különböző irányban nyomtatott próbatest kísérleti dinamikai vizsgálatát végeztük el.

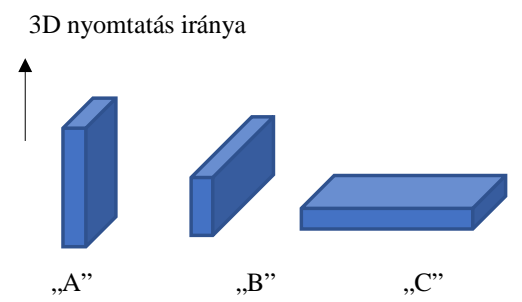

1. ábra. A próbatestek nyomtatási irányai

Egyik végén befogott tartóként vizsgálva meghatároztuk a próbatest $\mathrm{f}=0-850 \mathrm{~Hz}$ frekvencia tartományba eső hajlító és torziós sajátfrekvenciáit, csillapítási hányadosait és lengésképeit. Minden egyes módusra ellenőriztük, hogy a lengéskép klasszikus normál módusú-e, vagy sem. Mint ismeretes klasszikus normál módusok esetén a lengésképek állóhullám jellegủek, megegyeznek a csillapítatlan rendszer lengésképeivel és ezért matematikai modelljük kezelése lényegesen egyszerübb. A méréssel meghatározott módusokat szétválasztottuk 2 csoportra: hajlító, ill. torziós módusok csoportjára. A csillapítási mechanizmus identifikálása céljából regressziós függvényeket határozunk meg, melyek kifejezik a sajátfrekvenciákhoz tartozó csillapítási 
tényező frekvencia-függését [1]. Ezek a függvények közvetlenül kapcsolatban vannak a reológiából ismert veszteségi tényező függvényével. A veszteségi tényező a veszteségi modulusz és a tárolási modulusz hányadosa [1]. Általános esetben a veszteségi modulusz és a tárolási modulusz is a frekvencia függvénye, ezért ezek hányadosa a veszteségi tényező is a frekvencia függvénye.

Iterációs módszerrel meg fogjuk határozni azokat az anyagjellemzőket, amelyek mellett a végeselemes modell validnak tekinthető, amelyre legkisebb az EMA modell és a FEM modell sajátjellemzői (sajátfrekvencia, csillapítási tényező, lengésképek) közötti különbség.

A lengésképek összevetését a kísérleti munka következő fázisában kvalitatív módon fogjuk végezni. A további kutatási projekt keretében a végeselemes modell megfelelő redukcióját is el fogjuk végezni. Megvizsgáljuk, hogy a végeselemes modellezés választott környezetében milyen lehetőségek vannak a csillapítási adatok megadására és szisztematikus változtatására.

\subsection{Paraméterbecslés}

A mért frekvenciaválasz függvény (továbbiakban $F R F$ függvény) analitikus közelítő függvényét részlettört (parciális tört) alakban írtuk fel:

$$
H(j \omega)=\sum_{i=1}^{n}\left[\frac{P_{i}}{j \omega-\lambda_{i}}+\frac{\overline{P_{i}}}{j \omega-\bar{\lambda}_{i}}\right]
$$

ahol:

$P_{i}-$ i-edik módus reziduuma $\left[\frac{\mathrm{m} / \mathrm{sec}}{\mathrm{N}}\right]$

$\lambda_{i}-$ i-edik módushoz tartozó komplex sajátérték [ $\mathrm{rad} / \mathrm{sec}]$

$$
\lambda_{i}=-\sigma_{i}+j \omega_{d, i}
$$

$\sigma_{i}$ - i-edik modális csillapítás (modal damping) $\omega_{d, i}$ - i-edik módus csillapított sajátkörfrekvenciája.

$j$ - képzetes egység

Ezeket a modális paramétereket a mért $F R F$ függvény alapján becsüljük. Az egyes módusok azonban hatással vannak a többire (2. ábra), így ezek a becslések nem pontosak, szükség van egy optimáló függvényre.

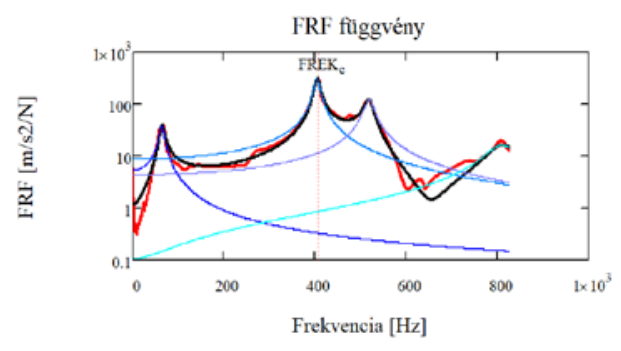

2. ábra. Az egyes részlettörtek egymásra való hatása

Az optimáló módszer a

$\varepsilon\left(P_{i}, \lambda_{i}\right)=\sum_{r=1}^{N_{r}}\left(H\left(j \omega_{r}\right)-\hat{H}_{r}\right)^{2}$

legkisebb négyzetes funkcionált minimálja.

$\hat{H}_{r}$ a mért és átlagolt FRF függvény értéke az $\omega_{r}$ körfrekvencián.

\section{Részeredmények}

A „C” módszerrel jelölt nyomtatott próbatest $F R F$ függvénye látható a 3. ábrán.

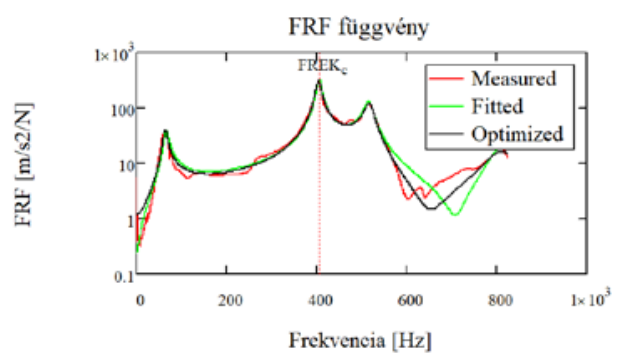

3. ábra. A „C” próbatest Frekvencia-válasz Függvénye, közelitö függvénye, és optimált közelitö függvénye. 
Ezzel a módszerrel 3 sajátfrekvenciát sikerült detektálnunk. A lengésképek osztályozását az FRF függvények Nyquistdiagramjainak segítségével végeztük el.

1. táblázat. A detektált lengésképek osztályozása

\begin{tabular}{|c|c|c|c|}
\hline Mode $i$ & 1 & 2 & 3 \\
\hline$f_{i}[\mathrm{~Hz}]$ & 65,3 & 406,7 & 520,3 \\
\hline$\xi_{i}[\%]$ & 5,01 & 1,294 & 1,098 \\
\hline Típus & $\mathrm{H}$ & $\mathrm{H}$ & $\mathrm{T}$ \\
\hline
\end{tabular}

A 4. ábrán három domináns módus modal köre figyelhető meg. További elemzéseket kell végezni a kisebb amplitúdójú (origó közelében lévő) módusok paraméterbecslése érdekében.

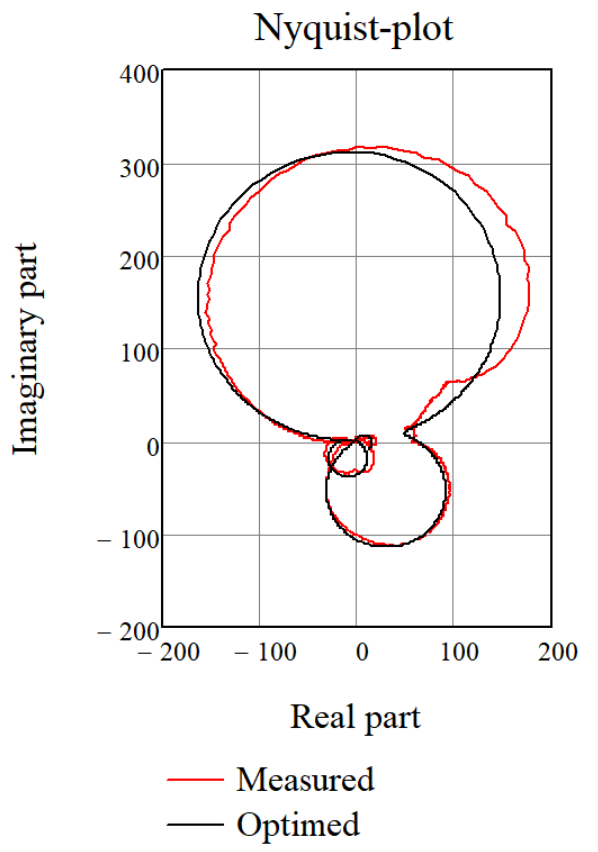

4. ábra. „C” próbadarab $7 Z 1 Z$ lokációhoz tartozó Nyquist-diagramja

\section{A kutatás további fázisai}

A fentebb említett regressziós függvényeket meghatározzuk, melyek kifejezik a sajátfrekvenciákhoz tartozó csillapítási tényező frekvenciafüggését. A vizsgált frekvenciatartományon mindössze 3 darab sajátfrekvenciát sikerült észlelni, amiket szétválasztva kettő hajlító, illetve egy torziós lengést kaptunk; ilyen kevés pontra regressziós függvényt nem tudunk felírni (az interpolációs függvények alkalmazását kerülni kell). A továbbiakban a méréstartomány szélesítésével már elegendő sajátlengést detektálhatunk, amik alapján már felírhatók lesznek a regressziós függvények. Az értékelést mindhárom próbatestre elvégezzük.

A várakozás szerint az anyagtulajdonságok modellezése nehézséget fog okozni a végeselemes modell inputjának megadásánál.

\section{Szakirodalmi hivatkozások}

[1] Pápai F.: Klasszikus normál módusú lengőrendszerek csillapítási modellezésének vizsgálata. XI. Magyar Mechanikai Konferencia, MaMeK, 2011, Miskolc, 2011. augusztus 2931, 1-11.

[2] Ficzere P.: Orthotrop anyagmodell alkalmazása additív gyártástechnológiával elöállitott alkatrész méretezése során, GÉP 67:(5-6) 7881 (2016)

[3] Tisza M., Kovács P. Z., Tóth D.:3D nyomtatás a jármüiparban, XXIX. microCAD International Multidisciplinary Scientific Conference, University of Miskolc, 9-10 April, 2015. ISBN 978-963-358-061-5

[4] Kis K.: Additív gyártástechnológiával elöállitható rugalmas müanyagok vizsgálata, TDK dolgozat, 2017.10.26. 10-50.

[5] Pauleczki P.: FDM nyomtatási eljárás vizsgálata PLA alapanyag esetében, Szakdolgozat, Budapest 2016, 4-34.

[6] Bodnár I.: Potenciálisan biodegradábilis, politejsav bázisú polimerek szintézise és vizsgálata, Doktori értekezés 2002. 1-26. 